recibido: 11.06 .13 / aceptado: 16.09 .13

\title{
La fotografía en la prensa: análisis comparativo del tratamiento de las imágenes de los terremotos de Haití (2010) y de Japón (2011) en la prensa española
}

Jessica Fernández Vázquez

Universidade de Vigo

\section{Palabras clave}

Análisis fotográfico, terremoto Haití, tsunami Japón, ética informativa, fotografía en prensa, fotonoticia.

\section{Resumen}

Informar sobre el terremoto de Haití de enero de 2010 y el tsunami que arrasó Japón en marzo de 2011 supuso un reto comunicativo para los periodistas, ya que los hechos pronto se convirtieron en noticias de primera plana en los medios internacionales dado el elevado número de víctimas mortales y la destrucción material provocada. Para los medios impresos, las fotografías fueron una herramienta fundamental para informar ya que, gracias a su capacidad para evocar sentimientos, a su poderío emotivo y a su fuerza comunicativa, acercaron a los lectores al lugar de los hechos transmitiendo la realidad de cada lugar. Tras un análisis formal y de contenido, con esta investigación se comprobó cómo el tratamiento fotográfico y la línea informativa de los principales soportes impresos de España, ABC, El Mundo y El País, fueron muy diferentes en cada uno de los casos objeto de estudio. Si comparamos las imágenes publicadas tras cada uno de los sucesos, nos encontramos con que a pesar de que las tres cabeceras coincidieron en la manera de tratar los hechos, la percepción social de cada país parece condicionar la representación del drama humano y de la destrucción, afianzando las ideas preconcebidas sobre cada uno de ellos. 
Photography in press media: comparative analysis of the treatment of the images of the Haití (2010) and Japan (2011) earthquakes in Spanish press.

\title{
Keywords
}

Photographic análisis, Haiti earthquake, Japan tsunami, informative ethic, press photograph, photonews.

\begin{abstract}
To report on the earthquake of Haiti of January, 2010 and the tsunami that devastated Japan in March, 2011 supposed a communicative challenge for the journalists, because the facts became international news. For the press media, the photographies were a fundamental resource to report the catastrophes, because they evoke feelings, have a emotive power and a big communicative force. After a formal analysis and content, with this investigation there was verified how the photographic treatment and the informative line of the principal press media of Spain, ABC, El Mundo and El País was very different in each of the cases object of study. If we compare the images published after each of the facts, we verify that the diaries coincided with the way of treating the catastrophes and that the social perception of the countries seem to determine the representation that they will have of the human drama and the destruction in the mass media.
\end{abstract}

\section{Autora}

Jessica Fernández Vázquez [jessicafdez@uvigo.es] es investigadora en la Universidad de Vigo. 


\section{Introducción}

Los terremotos de Haití y de Japón, sucedidos en enero de 2010 y en marzo de 2011 respectivamente, conmocionaron a la sociedad dada su fuerza, impacto y consecuencias entre la población alcanzando, en poco tiempo, repercusión mediática internacional. El terremoto de Haití, que alcanzó los 7.3 grados en la Escala de Ritcher, se cobró alrededor de 300.000 vidas, mientras que otras tantas sufrieron heridas de diversa gravedad ${ }^{1}$. Por otro lado, el terremoto de Japón alcanzó los 8,9 grados, lo que causó un posterior maremoto acompañado de olas de varios metros que asolaron parte de la costa japonesa. Según las cifras emitidas el 11 de junio del mismo año, tres meses después del temblor, el número de víctimas mortales se eleva hasta las 15.405 y el número de desaparecidos alcanzó los $8.405^{2}$.

Comunicar a la sociedad qué es lo que había ocurrido resultó un reto informativo y las imágenes se convirtieron en una herramienta clave para acercar a los individuos de todo el mundo al lugar de los hechos gracias a su capacidad para evocar sentimientos, a su poderío emocional y a su fuerza informativa. Sin embargo, y partiendo de la idea de que Japón y Haití son dos países muy diferentes, tanto en términos políticos como socioculturales y económicos, con esta investigación pretendemos dar respuesta a las siguientes preguntas: ¿qué realidad mostraban las imágenes publicadas por la prensa española? ¿cómo se trataron en España los acontecimientos? ¿existieron diferencias en la cobertura informativa entre uno y otro suceso o, por el contrario, los medios de comunicación siguieron la misma línea?

\section{Objeto de estudio, hipótesis y objetivos}

Obtener información sobre aquello que interesa es una necesidad básica que permite «satisfacer nuestra curiosidad sobre el mundo» (Arroyo, 2000: 27) y, hoy en día, la información visual es un elemento fundamental: no sólo trasladan y reflejan una determinada realidad sino que permiten a los espectadores o lectores obtener información de manera rápida, creíble y verosímil.

La presente investigación se centra en el estudio comparativo del tratamiento mediático a través de las imágenes de las dos catástrofes naturales de mayor relieve acaecidas en los últimos años. Con el fin de acotar el estudio, la muestra estará conformada por todas las fotografías publicadas en las ediciones impresas de los principales diarios españoles, ABC, El Mundo y El País, durante los dos días posteriores a la catástrofe: 13-14 de enero de 2010 y 12-13 de marzo de 2011. Esta elección de los días que comprenden el análisis no se realizó al azar, sino porque cubren dos de los elementos básicos de las noticias: el interés

1 Terremoto de Haití. Disponible en: http://www.noticiassin.com/2011/01/haiti-anuncia-actos-conmemorativos-aniversario-terremoto/ (08/06/2013)

2 Terremoto de Japón. Disponible en: http://www.europapress.es/internacional/noticia-elevan-15405-muertos-8405desaparecidos-tres-meses-terromoto-20110611083158.html (08/06/2013) 
general, es decir, la capacidad de los hechos para «convertirse en mensajes noticiables, elaborados desde la veracidad, (...) dirigidos a ciudadanías concretas y altos para ser divulgados en pro del bien común» (Acirón, 2006: 39) y la actualidad informativa mantenida en el tiempo, es decir «noticias en las que el elemento actual se prolonga en el tiempo porque su importancia transciende y se desarrolla a lo largo de varias jornadas. Por ejemplo, un suceso de cierta relevancia tiene inicialmente una actualidad reciente y si es importante y se prolonga a lo largo de varios días se convierte en una noticia de actualidad prolongada» (Armentia y Caminos, 2009: 218).

Se presenta una investigación que plantea los siguientes objetivos:

- Conocer el tratamiento mediático y la línea informativa a nivel fotográfico seguida por la prensa española ante dos de las catástrofes naturales más violentas de los últimos tiempos.

- Establecer una comparación entre ambos hechos, con el fin de conocer las diferencias y similitudes entre las líneas informativas seguidas.

- Definir cuál sería el tratamiento mediático ideal teniendo en cuenta la libertad de expresión, la necesidad de información por parte del público y la ética informativa.

A pesar de que la repercusión y cobertura informativa de ambos sucesos alcanzaron nivel internacional dado el impacto e interés social que generaron, las hipótesis planteadas al inicio de este estudio giran en torno a la existencia de un tratamiento informativo diferente en cada caso:

- El impacto de la noticia modificará la agenda informativa de la prensa española, alcanzando una gran repercusión mediática en ambos casos.

- Mientras que la imagen que se transmite de Haití está más ligada a la destrucción, el drama y la pobreza, las fotografías del tsunami de Japón serán menos cruentas, haciendo prevalecer la imagen de desarrollo y progreso tanto social como político y tecnológico del país.

- En ninguno de los casos hace un tratamiento informativo éticamente correcto, ya que se da prioridad al morbo y al sensacionalismo frente a la necesidad informativa del público.

\section{Método}

Las herramientas clave para llevar a cabo la investigación planteada serán el análisis de contenido y el análisis formal. Siguiendo a Piñuel (2002: 7), entendemos el análisis de contenido como «el conjunto de procedimientos interpretativos de productos comunicativos (mensajes, textos o discursos) que proceden de procesos singulares de comunicación previamente registrados y que, basados en técnicas de medida, a veces cuantitativas (estadísticas basadas en el recuento de 
unidades), a veces cualitativas (lógicas basadas en la combinación de categorías) tienen por objeto elaborar y procesar datos relevantes sobre las condiciones mismas en que se han producido aquellos textos, o sobre la condiciones que puedan darse para su empleo posterior», que aplicaremos al análisis fotográfico.

Como indica Berelson (1952, citado en Krippendorff 1980/1990: 29), el análisis de contenido se define como «una técnica de investigación para la descripción objetiva, sistemática y cuantitativa del contenido manifiesto de la comunicación» que «bascula entre dos polos: el del rigor que exige la objetividad y el de la fecundidad propia de la subjetividad del investigador».

Las imágenes tienen sentido en un determinado contexto, ya que «presentan el aspecto de personas, objetos, lugares o situaciones de una manera más clara, unívoca, rápida y exacta que una información verbal descriptiva sobre lo mismo. Sin embargo, la información global ofrecida por una fotografía será incompleta si el que la contempla no es capaz de reconocer a las personas que aparecen en la foto o saber realmente qué es lo que refleja» (Del Valle, 1993) porque «así como muchas fotos son entendibles con sólo mirar lo que hay en ellas, muchas otras son inescrutables sin alguna información que vaya más allá de la que reunimos con una simple observación de la imagen», tal y como recoge Abreu (2004) al referirse a los criterios de análisis establecidos por Terry Barret.

Teniendo en cuenta todo lo dicho anteriormente, para realizar el estudio se elaborará una tabla de análisis, tanto de contenido como de forma, introduciendo variables que aplicaremos a toda la muestra, con el fin de obtener datos susceptibles de ser tratados estadísticamente y comparados posteriormente para extraer conclusiones cuantitativas que lleven a la reflexión cualitativa. Como variables de contenido de la fotografía se analizará quién es el protagonista de la imagen clasificándolos en afectado, bombero, médico, cadáver y otros; qué elementos simbólicos recoge, diferenciando entre banderas, símbolos religiosos, ruinas u otros elementos y, por último, el contexto, es decir, calle, hospital, casas y otros. Cabe destacar que, dentro de la variable nombrada como «otros» se especificará claramente de qué se está hablando.

En cuando al análisis formal, se tendrá en cuenta la página, par o impar, en la que se localiza la fotografía; si es en color o en blanco y negro y, por último, el tipo de plano empleado por el fotógrafo.

\section{EI papel de la fotografía como elemento transmisor de información}

«La historia del documento fotográfico se vincula con la propia historia de la fotografía. Cualquier fragmento de la realidad es un fragmento de la vida o de la historia en sentido universal. La imagen fotográfica es, por consiguiente, un fragmento de la vida y/o de la historia» (Sánchez, 1996: 166). «La fotografía es como una cita, una máxima o un proverbio. Cada cual almacena mentalmente cientos de fotografías, sujetas a la recuperación instantánea. Cítese la más céle- 
bre realizada en la Guerra Civil española, el soldado republicano al que Robert Capa dispara con su cámara justo en el momento en que es blanco de una bala enemiga, y casi todos los que han oído hablar de esa guerra pueden traer a la memoria la granulosa imagen en blanco y negro de un hombre de camisa blanca remangada que se desploma de espaldas en un montículo, con el brazo derecho echado atrás mientras el fusil deja su mano; a punto de caer, muerto, sobre su propia sombra» (Sontag, 2004: 31-32).

En el caso de la información periodística, «se convierte tanto en su propio presente como, especialmente, al pasar del tiempo, en un auténtico documento social, reflejo de épocas, situaciones, personajes y ambientes» (Torregrosa, 2010: 330). Las imágenes tienen un gran poder de evocación, siendo un vehículo idóneo para la transmisión de ideas y realidades, «interrumpe, detiene, fija, inmoviliza, separa, despega la duración captando un solo instante (...). La foto aparece así, en el sentido fuerte, como una tajada única y singular de espacio-tiempo» (Dubois, 1986: 141). Su capacidad para perdurar en la mente y su atractivo visual las hace más llamativas que cualquier texto, convirtiendo la labor del fotoperiodista en una actividad clave para transmitir y confirmar los hechos. «La excesiva cantidad de información con la que se enfrenta el lector, característica de los tiempos que corren, ha llevado a que éste desarrolle mecanismos de selección» donde juegan un papel importante las imágenes como «gancho de lectura» (Minervin y Pedrazzini, 2004).

El fotoperiodismo se puede definir como «información fotográfica de actualidad. (...) En el extremo de máxima tolerancia, (o conformidad) fotoperiodística, podemos admitir toda fotografía reproducida por un periódico o revista, dentro de su cuerpo informativo, por su contribución - por mínima o colateral que resulte- al proceso de comunicar y hacer comprender acontecimientos de actualidad y de interés general» (Alonso Erausquin, 1995: 8-9). En una cultura dominada por la imagen, la fotografía aumenta su peso informativo, «de tal forma que en la actualidad un diario no sólo es confeccionado para ser leído sino también para ser visto» (Minervini y Pedrazzini, 2004). "Al ir incluida entre un texto, toma otro sentido, otro valor. La fotografía sirve para reforzar la información escrita, no ya como ilustración (aunque también), sino como demostración palpable de lo que se dice es verdad. Esta curiosa teoría, expresada por Gutiérrez Espada, no parece dejar otro camino a la fotografía, que el de acompañante de segundo orden y al servicio de la información escrita. No se cae, por lo tanto, en la cuenta de que una fotografía o serie gráfica (...) puede, y de hecho sucede, decir, expresar o proporcionar un tipo de información $-\mathrm{y}$, por lo tanto, de comunicación- más interesante e importante que cuanto puede leerse o escucharse, al recoger (...) en determinados casos, un gran número de datos y aportar al cliente o receptor de los medios escritos, más amplia información hablada o escrita, como sucede en la televisión, sobre un hecho o suceso» (Alcoba, 1988: 18-20). 
En este sentido, «el valor documental de la fotografía está, evidentemente, en su significado. La relación directa entre el texto y la imagen es esencial para cualquier investigación, y excepcional cuando se trata de matices» (Sánchez, 1996: 177). Sin embargo, no podemos obviar que la realidad es muy amplia y que una fotografía plasma una pequeña parte de ella y existen discrepancias sobre su nivel de veracidad. Como cualquier otro sistema de representación, «la fotografía (...) está lejos de proporcionar documentos verídicos e imparciales» (Lens, 2004: 153) ya que es el propio fotógrafo quién, de forma subjetiva, selecciona qué porción de la realidad capta para mostrar a los receptores que, a su vez, harán múltiples interpretaciones a partir de diferentes aspectos entre los que pueden estar sus experiencias personales, nivel socio-cultural, contexto social, etc., por lo que «la humanidad sigue irremisiblemente aprisionada en la caverna platónica, siempre regodeándose - costumbre ancestral- en meras imágenes de la verdad» (Sontag, 1981: 13).

Esta aproximación a la fotografía es necesaria para entender el papel que juegan estas imágenes en los soportes impresos. Como indica Sontag, los fotógrafos deben de aportar algo novedoso, causar impacto y por ello «la competencia no tiene límites, en parte a causa de la proliferación de imágenes de horror (...). Sufrir es una cosa; muy otra es convivir con las imágenes fotográficas del sufrimiento, que no necesariamente fortifican la conciencia ni la capacidad de compasión. También pueden corromperlas. Una vez que se han visto tales imágenes, se crea la incitación a ver más» (Sontag, 1981: 29-30).

Los medios como la televisión, cine o Internet, se valen de contenidos audiovisuales y con movimiento, capaces de atraer la atención de los espectadores o usuarios pero, ¿cómo captar la atención de los lectores cuando se «ha transformado el mundo entero en un inmenso plató» (Ferrés, 2000: 21) y prima el espectáculo? Las fotografías permiten destacar hechos, momentos y detalles de una realidad concreta, lo que le aporta credibilidad y gran capacidad de expresión, convirtiéndola en una fuente fidedigna de información aunque, en ocasiones, vaya acompañada de un efecto amarillista o sensacionalista. Su poder va más allá de su estatismo ya que, «lejos de convertirse en un impedimento, la posibilidad de congelar y fijar una imagen facilita que quede grabada en la memoria, con lo que la efectividad a largo plazo es mayor» (Torres, 2006).

\subsection{Cuando entra en juego la ética. ¿Publicar o no publicar?}

«La libertad es peligrosa si no va unida a la responsabilidad (...). La responsabilidad y la autonomía éticas se difuminan fácilmente cuando otros imperativos se muestran como dominantes e inescapables. El principal es el dinero. Los medios de comunicación efectúan un servicio público (...) pero son también una industria que debe ser económicamente rentable (...) y ocurre que el servicio al dinero suele anular la función de servicio público» (Camps, 1995: 53). Ante el impacto que pueden causar ciertas imágenes por su contenido, surge la eterna 
dicotomía entre la libertad de expresión y la satisfacción de las necesidades informativas por un lado y el derecho de los individuos al honor, a la intimidad y a la imagen por otro. Por ello, publicar o no publicar fotografías que puedan herir la sensibilidad tanto de las víctimas y sus familias como de los lectores sigue siendo un debate de actualidad, así como el derecho de hacer público aquello que es privado. En los resultados obtenidos tras del estudio realizado por la Universidad Pompeu Fabra en 2009, «se constató que todas las situaciones que generan dolor humano constituyen, en general, una de las cuestiones más polémicas y discutidas de la profesión, sobre la que los códigos suelen recomendar respeto a las víctimas y a la familia, así como un trato escrupuloso de la identidad de las personas afectadas (...). Mientras que en los periódicos, las radios y las agencias de noticias las actitudes son más laxas y favorables a mostrar las imágenes, en la televisión se es bastante más crítico» (Alcalá, Alsius y Salgado, 2009: 110-116).

Lo que queda claro es que «si la información es siempre importante, en situaciones de crisis como las provocadas por las catástrofes, todavía lo es más». El pánico puede condicionar las reacciones de los interesados, por lo que «una información clara, rigurosa, adecuada y a tiempo actúa como un mecanismo esencial de reducción de la incertidumbre, facilitando la toma de decisiones correctas» (Aznar, 2005: 82-83).

Según el Código propuesto por María Ángeles San Martín Pascal en torno a la fotografía, existe el «deber de no presentar con imágenes y fotografías catastrofistas los aspectos más negativos de los hechos noticiosos, tratando con ello de impresionar más fácilmente al receptor y de hostigar la morbosidad y el mal gusto» (Armentia y Caminos, 2009: 121). Llegados a este punto cabe preguntarse qué se publicó y qué se ocultó tras las catástrofes naturales objeto de estudio. Por ello, y dada la relevancia que tienen las imágenes en el mundo de la revolución tecnológica y visual, analizaremos a continuación las fotografías publicadas en las principales cabeceras españolas durante los dos días siguientes a las catástrofes naturales explicadas, siguiendo las pautas de análisis formal y de contenido estipuladas en el apartado referido a la metodología.

\section{Resultados del análisis fotográfico}

\subsection{Las imágenes publicadas tras el terremoto de Haití}

El terremoto de Haití dejó en la prensa española imágenes que ocuparon las portadas y las secciones relativas a información internacional. La destrucción, los heridos y las víctimas mortales conforman el contenido de la información que los tres diarios analizados publicaron en los días siguientes a la catástrofe. Los titulares «Un mortífero seísmo hunde aún más a Haití en su miseria» en El Mundo, «Muerte, dolor y caos» en El País y «Más de cien mil muertos» en $A B C$, marcaron las portadas de las tres cabeceras el 14 de marzo. El panorama que 
transmite cada uno de ellos es cruento desde la primera página, refiriéndose a Haití como uno de los países más pobres de Latinoamérica. En los tres casos, los protagonistas de las imágenes de la portada son fácilmente identificables, ya que las fotografías fueron captadas con planos cercanos, a todo color y donde se pueden apreciar detalles en los rostros de los protagonistas, lo que permite deducir su actitud, gestos y estado de ánimo. ABC y El Mundo coinciden con la foto de portada: un padre con su hija fallecida en brazos que mira directamente a cámara. En el caso de El País, la imagen que abre la edición del día 14 muestra el rostro de una mujer que intenta salir de entre los escombros y que mira de forma directa hacia el profesional que inmortaliza el momento.
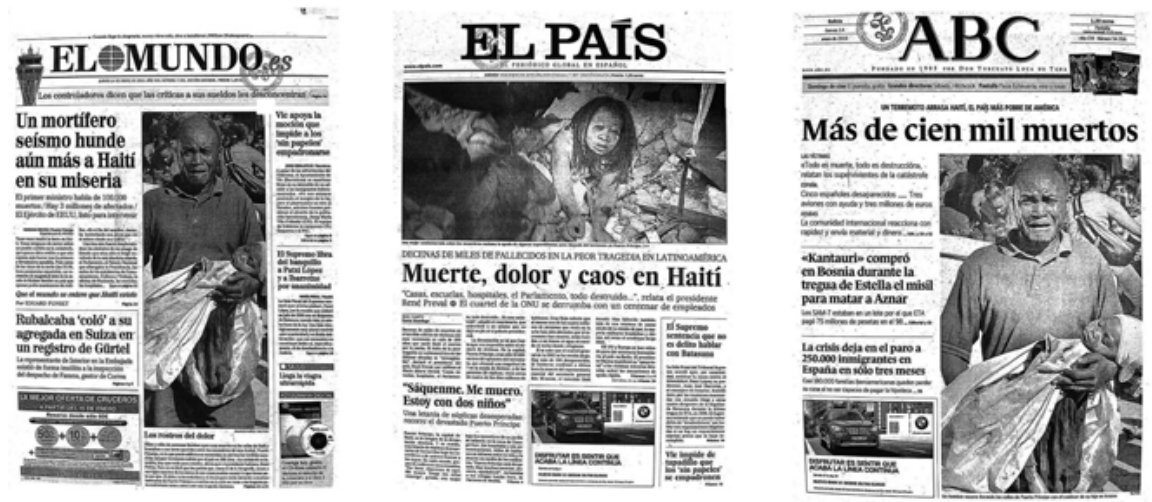

Imagen 1. Portadas de El Mundo, El País y ABC el día 14 de enero de 2010.

Respecto a las páginas interiores, $A B C$, El Mundo y El País coinciden tanto en el contenido como en el tema: prima la presencia de víctimas, especialmente niños, niñas y mujeres en un contexto de muerte y destrucción. Las imágenes son tanto directas, donde los rostros son fácilmente identificables, como indirectas, mostrando partes del cuerpo, ropa ensangrentada o sábanas que cubren heridos o fallecidos. Los planos son cercanos y a pesar de que se alternan fotografías en blanco y negro con imágenes en color, estas últimas son las que más abundan en El Mundo y en El País, mostrando de forma más clara la realidad que se vivía en Haití. El segundo de los elementos con más presencia en los medios fueron planos generales de la situación en la que quedaba el Palacio Presidencial, símbolo del poder haitiano y emblema de Puerto Príncipe. 

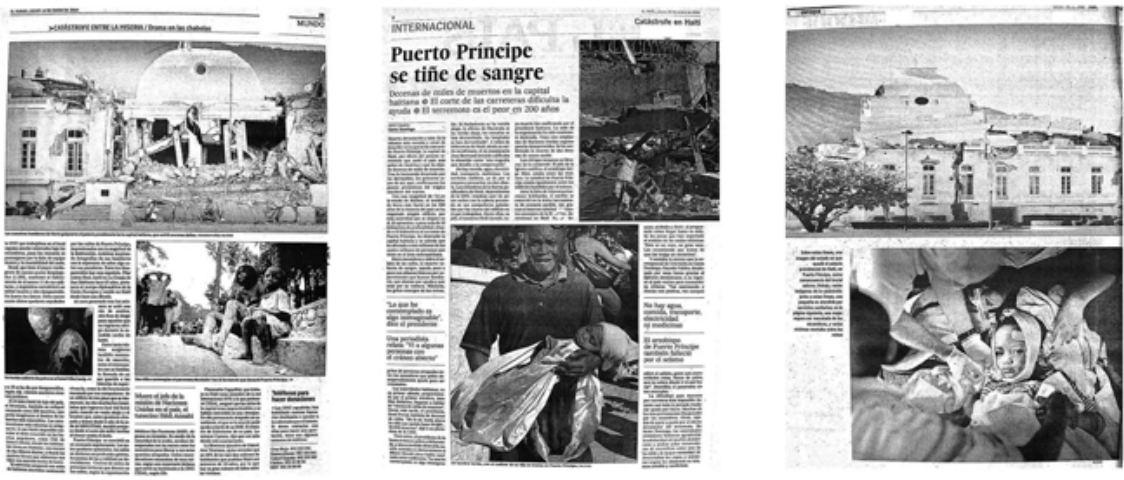

Imagen 2. Páginas interiores de El Mundo, El País y $A B C$ el día 14 de enero de 2010.

En este caso, las tres cabeceras parecen haber seguido una determinada línea informativa basada en mostrar la destrucción, con contadas excepciones: El País se sale del esquema en un par de ocasiones para mostrar a personal de la ONU inspeccionando la zona, así como la partida hacia Haití de la ayuda nacional. Por su parte, El Mundo muestra la ayuda estadounidense saliendo hacia el país así como la fuerza de un símbolo religioso, una cruz, que se mantenía en pie rodeada de escombros.

Teniendo en cuenta que las primeras imágenes que se publicaron en los diarios impresos fueron el día 14 de enero, dos días después del temblor, no podemos justificar la falta de material fotográfico o la premura de la noticia para hacer tal selección, sino que se intuye que fueron seleccionadas de entre un buen número de ellas. Que se trate de un suceso lejano para los medios justifica que casi todas las fotografías procedan de agencias y que muchas se publiquen en los tres periódicos a la vez pero, aún así, las tres redacciones siguieron criterios similares a la hora de seleccionar qué publicar:

Las víctimas fueron las principales protagonistas de la tragedia en los tres diarios. La mayoría de las imágenes muestran heridos, cuerpos de fallecidos, restos mortales o supervivientes atrapados entre escombros, así como sábanas blancas tapando cuerpos o restos de sangre.

La segunda categoría de imágenes con más presencia hace referencia al escenario tras el temblor, haciendo especial hincapié en el estado del Palacio Presidencial, símbolo político de la ciudad. 


\subsection{Las imágenes tras el terremoto de Japón}

Al día siguiente de la tragedia, el 12 de marzo, los tres periódicos que conforman nuestra muestra abren su edición con fotografías muy similares de la catástrofe japonesa. Bajo los titulares «La naturaleza ataca Japón» en El Mundo, «Una ola de muerte y destrucción» en El País y «Un tsunami barre Japón» en $A B C$, los diarios ampliaban la información que el día anterior adelantaban ya otros medios más inmediatos. En los tres casos, las imágenes a color nos muestran la estampa que dejaron las inundaciones provocadas por el tsunami tras el temblor e incluso existen instantáneas del mismo momento en que está sucediendo. En ninguna de las portadas se aprecian las víctimas, sino que son planos generales que muestran las ruinas, los destrozos o los incendios provocados. Este estilo se sigue en las imágenes interiores de la sección internacional de los diarios: fotografías del aeropuerto arrasado, aviones arrastrados por la corriente, carreteras inundadas, casas y construcciones destrozadas y el remolino gigante que se formó en aguas próximas a la costa.
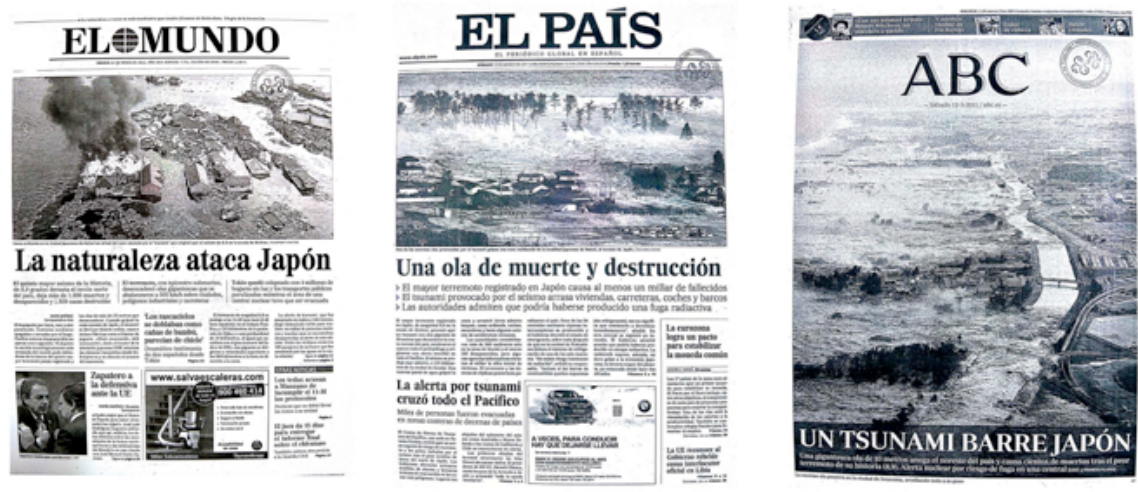

Imagen 3. Portadas de El Mundo, El País y ABC el día 12 de marzo de 2011.

Las imágenes muestran mediante planos generales el estado de las calles y ciudades con fotografías a todo color en su gran mayoría. No existen imágenes que muestren víctimas mortales o heridos, exceptuando una fotografía publicada en El Mundo en la que se puede apreciar a víctimas y heridos asistidos por los servicios de emergencia, pero captada a gran distancia desde el aire y $\sin$ mostrar detalles.

Mientras que en este primer día tras la tragedia el tema principal es la destrucción de las ciudades, el día 13 de marzo todas las miradas se centran en la central de Fukushima y en el temor a una catástrofe nuclear. El País dedica su portada a la explosión de uno de sus reactores mediante un plano general 
a todo color, donde se puede apreciar la nube de humo generada. En torno al mismo tema, El Mundo recoge, en color y con un plano cercano, el momento en el que los técnicos chequean los niveles de radiación de dos menores. Por su parte, $A B C$ insiste en mostrar la destrucción de las calles, pero esta vez con los afectados en primer plano aunque aparentemente ilesos y calmados.
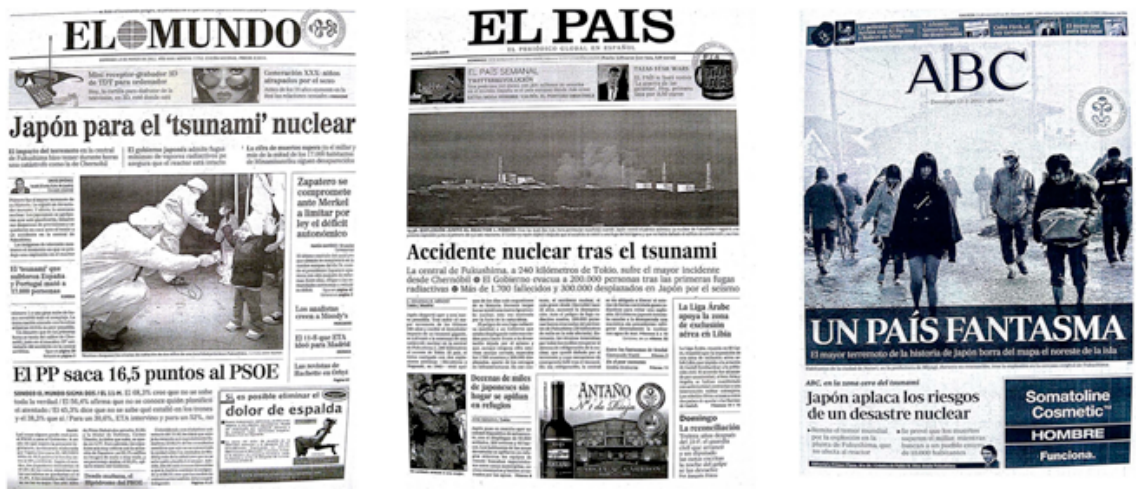

Imagen 4. Portadas de El Mundo, El País y ABC el día 13 de marzo de 2011.

Ya en las páginas interiores, la tónica es similar y en ningún momento se ven heridos o cadáveres, sino que en el caso de Fukushima, las evacuaciones y las calles cobran protagonismo. Las imágenes reflejan la previsión y preparación para una posible explosión: muchos llevan cascos, mascarillas o trajes y material especial. Su actitud es de calma y orden frente a la desesperación haitiana y los fotografiados caminan entre los escombros, pero no se aprecian heridas visibles o graves ni cadáveres.

\subsection{Comparación de resultados}

En función de los resultados obtenidos de cada análisis individual, obtenemos que, a pesar de ser catástrofes similares y de existir entre ellas un margen de tiempo que se puede considerar reducido, los soportes mediáticos de la prensa española siguieron líneas informativas similares entre ellas pero diferentes para cada uno de los casos.

Aunque los sucesos ya habían sido tratados en otros medios de comunicación más inmediatos como la radio, televisión o Internet, las imágenes de los diarios jugaron un papel fundamental para sensibilizar a la población, concienciar de lo sucedido y trasladar al lector al lugar de los hechos de una forma directa. Que se trate de un hecho lejano que sucede de forma imprevisible condiciona 
que las fotografías publicadas sean de agencia, por lo que se repiten en los tres periódicos en varias ocasiones.

En el caso de Haití, las imágenes publicadas en $A B C$, El Mundo y El País tenían como protagonistas a las víctimas, en especial a niños, niñas y mujeres. La reproducción de cadáveres, escenarios cruentos y heridos fue la tónica general que siguieron los soportes analizados que, a pesar de pertenecer a grupos de comunicación diferentes, coincidieron en la manera de reflejar la realidad haitiana. Con ellas se reflejaba la pobreza, la destrucción y el dolor de un país que no estaba preparado ni capacitado para soportar un desastre de tal magnitud.

Cuando se habla del terremoto y posterior tsunami que asoló Japón, la línea informativa vuelve a ser similar en los tres soportes que conforman la muestra, aunque muy diferente al tratamiento informativo dado en el caso de Haití. Las imágenes más repetidas por $A B C$, El Mundo y El País son instantáneas de las ciudades, calles y casas destrozadas por la violencia de los movimientos sísmicos, con planos generales en la mayoría de los casos. Le siguen en cantidad imágenes que dejan un mensaje de progreso social, preparación para situaciones extremas, orden y el civismo de la población.

\section{Conclusiones}

Tratar a nivel fotográfico tragedias como las que conforman el objeto de estudio siempre resulta un gran reto periodístico donde la prensa y el resto de los medios juega un papel complicado para establecer el equilibrio responsable entre la necesidad informativa de los públicos, la libertad de expresión y el derecho al honor, intimidad e imagen de las víctimas directas e indirectas.

Tras el análisis comparativo realizado, podemos concluir que los medios españoles alteraron su agenda informativa para dar prioridad a ambos sucesos, cumpliéndose de esta manera la primera de las hipótesis. Aunque las fotografías procedieran de agencias, es especialmente llamativo que cabeceras pertenecientes a grupos de comunicación diferentes como son ABC, El Mundo y El País, coincidieran en seguir la misma línea informativa en cada caso: mientras que al tratarse de Haití las imágenes contaban con la presencia de fallecidos, en el caso de Japón se omitió este tipo de información, proporcionando fotografías menos cruentas en donde es más difícil encontrar alguna imagen en la que se puedan apreciar victimas mortales o heridos de gravedad, tal y como se planteaba en la segunda de las hipótesis.

¿Es legítimo publicar imágenes sobre las víctimas mortales y heridos? Independientemente de las razones económicas que puedan mover a los medios, «en situaciones así, el profesional debe tener presente más que nunca el estado de los protagonistas de la información, evitando banalizar lo que para ellos es una situación dramática que seguramente no olvidarán jamás» respetando «a los afectados, dada la merma de su capacidad de reacción y su estado anímico, 
procurando siempre evitar la implicación de menores» (Aznar, 2005: 93). Si tenemos en cuenta que en ambos casos las víctimas mortales se cuentan por miles y que las imágenes de ambas tragedias podrían ser similares a la hora de representar el drama humano, concluimos que la única razón que puede justificar la diferencia de trato en ambos casos y la coincidencia de cada uno de los soportes que conforman la muestra a la hora de definir su línea informativa es mantener la percepción social existente sobre Haití y sobre Japón: cuando se muestra la realidad haitiana se afianza la idea de pobreza, destrucción y desamparo, apelando a la sensibilidad del lector a la hora de movilizar conciencias y cooperar con la causa, mientras que cuando se habla de Japón, las imágenes revelan orden, progreso y preparación previa ante catástrofes imprevisibles, existiendo incluso material gráfico y visual del momento exacto en el que estaban sucediendo los hechos.

Pese a que el morbo y el sensacionalismo que causa la publicación de imágenes con heridos y víctimas, hay que recordar que existen fotografías muy duras que tuvieron un gran calado social y que ya forman parte de la memoria colectiva. Por ello, y tras realizar el estudio, concluimos que el tratamiento informativo realizado sobre la tragedia japonesa revela la posibilidad de transmitir la realidad social sin la necesidad de mostrar a las víctimas de forma directa y respetando su privacidad, refutando de esta manera la tercera y última hipótesis de partida.

\section{Bibliografía}

Abreu, Carlos (2004). El análisis cualitativo de la foto de prensa. En: Revista Latina de Comunicación Social, núm. 57, enero-junio. Disponible en http://www. ull.es/publicaciones/latina/20040757abreu.htm (02/06/2013).

Acirón Royo, Ricardo. (2006). Papeles sueltos. Las Palmas de Gran Canarias: Idea Universidad.

Alcalá, Fabiola, Alsius, Salvador y Salgado, Francesc. (2009). El uso de imágenes de personas muertas en la televisión y otros medios de comunicación. La opinión de los periodistas en Cataluña. En: Quaderns del CAC, núm. 33 pp. 109-117. Disponible en http://www.cac.cat/pfw_files/cma/recerca/quaderns_ cac/Q33_Alcala-Alsius-Salgado_ES.pdf (20/05/2013).

Alcoba, Antonio (1988). Periodismo gráfico (fotoperiodismo). En: Castellanos, Ulises. Manual de fotoperiodismo. Retos y soluciones, México D.F: Universidad Iberoamericana Ciudad de México.

Alonso Erausquin, A. (1995) Fotoperiodismo: formas y códigos. Madrid: Síntesis.

Armentía Vizuete, José Ignacio y Caminos Marcet, José María (2009). Redacción informativa en prensa. Barcelona: Ariel Comunicación. 
Arroyo Almaraz, Isidoro. (2000). Ética de la imagen. Madrid: Laberinto Comunicación.

Aznar, Hugo (2005). Ética de la comunicación y nuevos retos sociales. Códigos y recomendaciones para los medios. Barcelona: Paidós.

Camps, Victoria (1995). El lugar de la ética en los medios de comunicación. En Bonete Perales, E. Éticas de la información y deontologías del periodismo (coord.). Madrid: Tecnos.

Del Valle, Félix (1993). El análisis documental de la fotografía. En: Cuadernos de Documentación Multimedia, núm.2, junio, edición revisada versión 2001. Disponible en http://pendientedemigracion.ucm.es/info/multidoc/multidoc/revista/num2/fvalle.html (08/06/2013).

Dubois, Philippe. (1986). El acto fotográfico. De la representación a la recepción. Barcelona: Paidós.

Ferrés Joan (2000). Educar en una cultura del espectáculo. Barcelona: Paidós.

Krippendorff, Klaus (1980/1990). Metodología de análisis de contenido: teoría y práctica. Barcelona: Paidós.

Minervini, Mariana y Pedrazzini, Ana (2004). El protagonismo de la imagen en la prensa. En: Revista Latina de Comunicación Social, 58, julio-diciembre. Disponible en http://www.ull.es/publicaciones/latina/20042058minervini.pdf (08/ 06/2013).

Lens Leiva, Jorge (2004). Fotografía y 11 de septiembre. La (de)construcción de una imagen a través de los medios impresos, En Pena, Alberto. (coord.), Comunicación y guerra en la historia. Santiago de Compostela: Tórculo Edicións, pp. 149-158.

Piñuel Raigada, Jose Luis (2002). Epistemología, metodología y técnicas del Análisis de Contenido. Estudios de sociolingüística, Vol.. 3.1. pp. 1-42.

Sánchez Vigil, Juan Miguel (1996). La documentación fotográfica. En Revista General de Información y Documentación, vol. 6-1. Madrid: Servicio de Publicaciones U.C.M. pp. 161-193.

Sontag, Susan. (1981). Sobre la fotografía. Barcelona: Edhasa.

Sontag, Susan. (2004). Ante el dolor de los demás. Madrid: Punto de lectura.

Torregrosa Carmona, Juan Franciso. (2010). Modelos para el análisis documental de la fotografía. En Documentación de las Ciencias de la Información, vol. 33, pp. 329-342. Disponible en http://revistas.ucm.es/index.php/DCIN/article/ view/DCIN1010110329A/18753 (04/06/2013).

Torres Romay, Emma (2006). El tratamiento de la imagen en los atentados del 11-M. Terrorismo y violencia en prensa. En Revista Latina de Comunicación 
Social, núm. 61. Disponible en http://www.revistalatinacs.org/200603torres.pdf $(04 / 06 / 2013)$.

\section{Referencia de este artículo}

Fernández Vázquez, Jessica (2013). La fotografía en la prensa: análisis comparativo del tratamiento de las imágenes de los terremotos de Haití (2010) y de Japón (2011) en la prensa española. En: adComunica. Revista Científica de Estrategias, Tendencias e Innovación en Comunicación, $\mathrm{n}^{0} 6$. Castellón: Asociación para el Desarrollo de la Comunicación adComunica, Universidad Complutense de Madrid y Universitat Jaume I, 189-204. DOI: http://dx.doi. org/10.6035/2174-0992.2013.6.11 